\title{
"Say Cheese": Family Photos, Modern Malay Masculinity and Family Narrative in Some Malaysian Films
}

\author{
JAMALUDDIN AZIZ \\ Universiti Kebangsaan Malaysia
}

\begin{abstract}
Family photographs are often used as a prop in a set-up of a family home in a film. Employing visual culture approach, I would argue that through the use of family portraits both in figurative and artefactual forms, the narrative about family is often unravelled, challenged and subsequently validated. A close textual analysis of three P. Ramlee's films that mark the dawn of modernism in the immediate post-independence Malaya and the formation of Malaysia in 1963 as a case study, this paper asks the following questions: What types of narratives are created through the display of family portraits? How do these family portraits reflect the changing conceptions of the institution of the family especially pertaining to modern Malay masculinity? And, how do family photographs inform family narratives? The analysis finds that, on one hand, family portraits are used to narrate the exteriorization of masculinity in trouble by revealing its castration anxiety. On the other, they also point to "the hero journey archetype" that apotheosizes masculine dominance as proven by the films' happy ending. The implication of this study lies in the way family photographs in films can be understood not merely as props, but in visual culture sense, as locating the source of the conflict of modern Malay masculinity in the family itself. Although family portraits in these films are meant to be innocuous to Malay masculinity in crisis, it is ideologically a folie de grandeur about the family and what it means for the nation in transition.
\end{abstract}

Keywords: Family narratives, family photographs, malaysian films, visual culture, masculinity.

\section{INTRODUCTION}

The oldest of all societies and the only natural one is that of the family. [Jean-Jacques Rousseau, 1762 (2012), p.7]

This article is triggered by one particular cinematic experience, a moment in film watching that travels through the passage of time to the present and most probably to the future. The film that I am talking about is Alfonso Cuaron's Gravity (2013) and the moment that I was referring to is the one when one of the female protagonist's colleague's face was damaged by flying debris, and attached to his disfigured face was the portrait of his family. Ironically, this flat cardboard-cut male Asian character, in the tradition of Hollywood stereotypes, was not supposed to be seen and remembered (IMDB.com even credits the character as playing a "voice"). Indeed, initially, his playful behaviour towards the female protagonist while floating in outer space borders annoyance. Therefore, the audience's initial reaction to his "mischief" provides a stark emotional contrast to the tragic tableau that ensues: as his floating dead body edging closer towards the agonizingly nervous female protagonist (Dr. Ryan Stone) in outer space, the camera provides vividly contrasting images between his disfigured face and his smile in his family portrait. 
Consequently, the juxtaposition of the disfigured face with the happy family photo provides a crucial moment in the film in which the emotional interior of the film is ultimately exteriorized, setting the tone of the rest of the film. The majestic opening scene of the film which is a vast outer space is then effectively reduced to this particular moment, which concatenates the initial shifts of points of view with that of Dr. Stone's, who later becomes the audience's emotional and visual center. As the juxtaposed images create a cinematic moment that is seen from Dr. Stone's visor, it is irrevocably frozen on the screen, in mind, and in time - immensely affecting the female protagonist and the audience alike. So crucial is the scene to the narrative of the film that it illuminates one of the central themes, that is, the existential need for human connection. The shock is necessary for Dr. Stone (and the audience alike) as these images are salient reminders of what really matters in the time of crisis or life in general. This realization, as she is incessantly reminded by the photo of her daughter, is a driving force that helps her emotionally and physically to go back home to her daughter, her only family.

A family is often regarded as the microcosm of a society and its power structure is often reflected in the family photo or portrait. Sturken and Cartwright argue, "[t]o explore the meaning of images is to recognize that they are produced within dynamics of social power and ideology" (2009, p.22). This essentially means that a nation or country can be studied and understood by looking at the cultural organization of the family and vice versa. Indeed, Benedict Anderson sees the connection between the family and a nation, arguing that "the family-as-articulated-power-structure" (1991, p.143) is a salient expression of the idea about a nation as both the mirror and the reflection of the ideological underlining of a society. This is akin to Althusser's idea that a family, as an institution, is an example of "ideological state apparatuses", as he argues that "an ideology always exists in an apparatus, and its practice, or practices. This existence is material" (2004, p.695). Therefore, how a family is structured or organizes itself speaks volume of how a nation organizes itself. In that vein, it can be argued that in its artifactual form, family photos can provide an indication of the power structure of the family; hence, the society.

Throughout history, family portraits are indicators of the politics of power within a society. Annette Kuhn (2007, p.284) suggests that:

In most societies, family photographs have considerable cultural significance, both as repositories of memory and as occasions for the performance of memory. A study of these processes can be helpful in understanding how the personal and the social aspects of remembering to interact in various cultural settings.

I see Kuhn's argument as relatable to the idea of class memory and power. For the aristocrats or the upper classes, earlier family portraits that come in the form of paintings are significant class indicators or markers, reflecting not only the power relations within the family but also the need to remain visibly powerful within its society. The working class or the proletariat might not have the means to capture a family portrait, nor did it have any need for one. Therefore, one can easily assume that the aristocrat's use of family portrait remains paramount in recording their existence, and in Michel Foucault's sense of knowledge and power schism, the proletariat's lack of family portrait, meanwhile, also means the erasure of their personal histories, where visibility equates to power and vice versa. Indeed, Sturken and Cartwright aver that "[p]hotographs have been used to prove that someone was alive at a 
particular time and place in history" (2009, p.17). This resonates well with what Patricio Guzman famously says: "A country without documentary films is like a family without a photo album" (www.patricioguzman.com). What the relationship between the family and photography ironically evinces is the possibility for historical accounts of a society prephotography to be easily conjectured.

The development in photography parallels the changes that are taking place in society. Photography permits visibility as "description is the essence of photography" (Li \& Zeng, 2019, p.1173). For instance, it can be said that photography as a modern invention liberates class distinction with its ability to be mass-produced. It has allowed the recording of global, national and personal histories, capturing moments that can be concatenated with the development or destruction of a society. This visual recording offers a description of the world that permits human beings to make sense of the world they live in.

This paper aims at exploring the use of family photos or portraits in some Malay films of the $60 \mathrm{~s}$, framing the analysis within the historical moments of the nation of that time, that is, the immediate post-independence Malaya. This is done for the purpose of revealing some ideological motives that inform the use of family portraits in Malay films, while illuminating ideological shifts related to the conception of the family, hence the nation. There is no denying that the concepts of the family have been reinvented, reimagined and de- and reconstructed through popular culture and also literature. I would like to argue that one way of understanding the constant changes in the idea about the family is by looking at the family portrait or photo.

Commonly, family photos are often considered or seen as a prop in a set-up of a family home in a film. Nonetheless, by positioning this article within the visual culture rather than visual communication paradigm, I would argue that through the use of family photos or portraits both in figurative and artifactual forms, the narrative about family is often unravelled, challenged and subsequently validated. Parsons $(2009$, p.301) argues that "Still photographs in films can create a space or a pause that invites an affective response". By using close textual analysis of some Malaysian films, this paper looks at the uses of family photos in some selected P. Ramlee's films in the 1960s, that is the period after Malaya had its independence in 1957 and the formation of Malaysia in 1963 as a case study, asking the question: What themes can be drawn through the display (or lack of) of the family photos? Conterminous with that, I also ask: How do these family pictures reflect the changing conceptions of the institution of the family especially pertaining to modern Malay masculinity? and How do family pictures inform family narratives? Using a purposive sampling technique, the films analyzed are Madu Tiga (1964), Masam-masam Manis (1965), and Sesudah Subuh (1967). Another reason for choosing these films is because their central concern is the family.

\section{Photography and Modernity}

Photography as technology is epochal as it dismantles the old-world view governed by Feudalism and it further determines how the new world order is perceived and understood. In that vein, Maggie Humm argues that "photography is a tool ... not simply as a documentary device but as a means of crossing the border between the visual and the unconscious" (2003, p.IX). Such is the power of photography that it can be seen as heralding the dawn of modernism in which class structure is consistently challenged by the ability of technology to help the mass production of images. As an example, the hugely priced majestic portrait 
paintings of aristocrats donning their bourgeois dwellings were not only made mundane, hence price-less, by their mass reproduction in the market place, but importantly, photography dilutes the ostensible class and gender monotheism that marks the preindustrial age.

Indeed, a new consciousness about the world that marks the end of class sovereignty is a poietic creation of photography that rearranges power structure, from the act of being gazed at to the act of gazing at. This I would say harks back to Becker's $(1974$, p.5) claim that in the early stage of photography it "strove toward art", highlighting the shared ability of photography and art to transgress social norms and expectations. I would like to use an example to illustrate this transgression of power shift. Heavily baroque ornamental aristocratic paintings, for instance, are often hung in such a way that the subjects of the painting, usually of a lord, gaze at the viewers. This positioning of the portrait resembles Foucauldian panopticon metaphor of omnipresence, power and surveillance. Hasan Sazali and Lutfi Basit posit that, in a panopticon, "the control object [domestic staff, for example] is aware of its permanent visibility and therefore complies with all the rules" (my addition) (2020, p.324). With the mass production of art portrait afforded by photography, photos can be held in palms, and become the object to be gazed at. This marks the shift of power through the politics of looking itself, the viewer now has the power to decide on how a portrait is to be seen, echoing Anthony Giddens' argument that "autobiographical cultural products (among which we could include photo albums) both shape and reflect the subject of modernity" (in Maggie Humm, 2003, p.13). Scott, likewise, talks about class liberation afforded by photography and photograph: "The camera's levelling, the democratic potential was apparent from the start, as middle-class families sat for formal portraits in local studios" (2011, p.4).

One important myth regarding photography is that it is used merely to record something. However, the roles of photography have been determined by both the technology and the photographer itself. This relationship is crucial in understanding the poetic of power with regards to images created by photography. Indeed, according to Becker (1974, p.3), "[f]rom its beginnings, photography has been used as a tool for the exploration of society and photographers have taken that as one of their tasks". Therefore, a photograph should be seen as a form of material culture that is inflective of both the cultural background of the photographer as well as his or her politics. For that reason, photographs are never valueneutral; they are constituted by what Pierre Bourdieu terms as "distinction: [...] which generally means having a refined, educated, sophisticated and aesthetic worldview, rather than simply seeing, evaluating and categorizing things 'naively' (in Schirato \& Webb, 2004, p.17). A photograph is therefore both a literal (artifactual) and metaphorical (cultural) frames that offer meanings in the practice of looking.

There is a preponderance of studies on photography; one crucial perspective locates the scholarly works within the affect studies. Scholars such as Roland Barthes in Camera Lucida (1981) and Susan Sontag in On Photography (1977) and her review of her initial idea in Regarding the Pain of Others (2003) are seminal works on photography affective dynamics and power, pivoting their arguments on emotions that are attached to the practice of reading a photo, which as Barthes comments: "to do, to undergo, to look" (1977, p.9). While Barthes' journey to understand a photograph is personal, that is after the death of his mother, Sontag (2003), on the other hand, warns about the danger of using a photograph to yoke communal emotion over the form itself, hence desensitize viewers of human suffering, that is often done in critical tradition. This theorization is further extended by Elizabeth Edwards, whose review 
essay entitled "Object of affect: Photography beyond the image" (2012) ideates the notion that by placing photographs in "assemblages of objects" as well as "considering new anthropological scholarship examining the 'embodied responses and emotional affects' entailed in photographic images" (in Cartwright \& Wolfson, 2015, p.143), the location of emotion must be within the form itself. "Photography", as argued by Hariman (2018, p.494), "wants us to find the value in shared seeing". This, to my mind, is the essence of visual culture itself in which the experience of seeing is inherent in the practice of looking itself.

Therefore, the study of the significance of family photographs in some selected Malaysian films is an effort to further investigate how family photos are used to mirror the struggle of modern society, and in this case, modern Malay masculinity in P. Ramlee's films. Sturken and Cartwright argue that "photographs are also objects in which we invest deep emotional content" (2009, p.18), making it central to this enquiry the need to identify the ways these photos are used within a certain historical context as mediated by the selected films. The historical context in this paper is the temporal context of the films produced.

\section{A Brief Review of Malay Films and Modernity}

The historical accounts of Malay films have been widely written about elsewhere. Writers such as Hatta Azad Khan, in Malay Cinema (1997), and Hassan Abd. Muthalib, Malaysian Cinema in a Bottle (2013), have written extensively on the subject. In sum, their writings provide extensive historical accounts in an effort to define what Malay or Malaysian cinema is. This section briefly describes some past studies on Malay films and its relationship to modernity.

The link between modernity and Malay films has been established during the golden age of Malay cinema. Barnard (2005) studies a collection of films coalesced by blindness as a theme in his article entitled "Sedih sampai buta: blindness, modernity and tradition in Malay films of the 1950s and 1960s". Published in 2005, the article explores the conflicts faced by the Malays in facing demeaning modern lifestyles as embodied by Singapore and other cities as the films' settings. Often rooted in the idea that traditional values and beliefs can have debilitating effects on the struggling Malays, the protagonists' experiences in the city can literally cause physical blindness. Barnard opines that the films' use of blindness as a cinematic trope reflects

"[t]he explicit break with tradition and the past - which is the essence of modernity - is often treated in these films as a binary battle between past and present. Blindness thus acts as a metaphor for the distance between traditions and modernity, the kampung and the city" (p.434).

One of the first well-known studies that internalize the roles of films in nation-building in the Malaysian context is the one done by Zawawi Ibrahim. Zawawi Ibrahim studies the cinema of Rahim Razali to expose the evolution of Malaysian cinema while arguing that his films "remain an important commentary on and critique of the Malay modernisation project that unfolded with the New Economic Policy (NEP), initially introduced by the Prime Minister Tun Abdul Razak in 1970" (2007, 515). According to Zawawi, the theme of the "New Malay" transcends many of Rahim Razali's films, the lynchpin of which is the family. This is because, according to him, 
"Rahim is a strong believer that Malay identity is intricately connected to the integrity of keluarga (family) and its structure" (p.517).

Zawawi offers an interesting conclusion by saying that "[e]ven if his critique of Malay modernity and his representations of Malayness in the face of modernisation are often essentialist, homogenizing and selective, the issues that he has raised do capture the imagination of the thinking mind", foregrounding the prevalence of Rahim Razali's films' focus on the Malay and modernity.

An article entitled "Film Melayu: Nationalism, modernity and film in a pre-World War Two Malay magazine" (2010) was written by Timothy P. Barnard and published in Journal Southeast Asian Studies. In this article, Barnard investigates "the nationalistic discourses, as well as discussions of modernity" (p.48), addressed in the first Malay film magazine, Film Melayu, to establish structural and functional links between film and nation-building. Barnard reveals that,

\footnotetext{
"the possibilities that the technology and narrative abilities that film held for conveying modern ideas and concepts excited many Malay nationalists who worked in the world of journalism. The film was a tool for modernising the nation (bangsa)" (p. 61-62).
}

This study, through the analysis of Film Melayu, is crucial as it shows how film as a technology, cultural expressions and metaphor can be used to aspire a nation in growing cosmopolitan milieu.

What this brief review of past studies on Malay films and modernity reveals is that films are a conduit in which the struggles faced by Malay society in facing modernity can be expressed. The present article looks at how photograph - in this case the family portrait -, as a modern invention, is used to reveal about the family and its organization of gendered power of a nation in transition.

\section{Analysis and Discussion}

The analysis of the films selected is organized around the three research questions. One, what types of narratives are created through the display of the family portrait? Two, how do these family photographs reflect the changing conceptions of the institution of the family especially pertaining to modern Malay masculinity? And three, how do family photographs inform family narratives? Though these three questions are separated, the practice of textual analysis usually produces inter-mingling discussions that reveal the overarching themes. As the samples chosen are films during the immediate post-independence Malaya, I would also argue that these films reflect an era of uncertainties and anxieties in Malay cinema, and in the case of P. Ramlee's films, this sense of uncertainties and anxieties coalesced in the figure of a family photograph.

Madu Tiga (1964), or its English title Rival Three, is a satirical film that falls under the family drama genre; it offers a critical view of the Malay Muslim man with a plot that centers around his attempts at building and keeping his marriages. In this film, P. Ramlee ventures into the familiar and familial territory to subtly criticize, not the marriage institution itself, but the flaws of the Malay Muslim man himself. Utilizing dramatic work akin to the comedy of manner, P. Ramlee puts his male protagonist, Jamil, under the critical microscope. It is his standard as a Muslim man that is under scrutiny, and this is built upon the character at the 
outset of the film as a strict managing partner of the family business and a loyal husband: "Don't think I am like Jaafar, Hashim and Salleh". Latifah and Jamil live in a palatial house that is as clean as a whistle; it is void of any personalized belongings and painted 'sanitized' white. This creates, despite Jamil's friendly communication with his wife, a sense of distance between them. Indeed, apart from the marital bed, there is no evidence of their intimacy and love for each other as a married couple.

The conflict of the character and the story unfolds with the scene in which after getting caught for marrying his second wife without his first wife's (Latifah) permission, but with the father-in-law's blessing: "You are a man", Jamil's life turned topsy-turvy. From then on, the film constantly portrays him as a man searching for happiness and a happy family. A clue to this yearning for a family comes from an unexpected place, in an expected way. His father-inlaw, albeit in comical tone and a sarcastic nod to the wise man archetype, appeals to his daughter's understanding of Jamil's need to remarry due to his status as an orphan. Besides, his marriage to his first wife does not produce any child (Jamil jokes about her being barren during his second wedding speech), which becomes a reason why he looks for a new younger wife, Hasnah. What is interesting about this is that the yearning for a family, for human connection, is shown as infantile by the way Jamil goes about solving his problems with his warring wives.

Unhappy with the war between his two wives, Jamil happens upon the potential third wife while going his round collecting rents. This portrayal of a polygamous Jamil as a well-todo modern Malay man living in a city is consciously done to allow viewers to accept Jamil's intention to seek a new wife; the effect is innocuous as the two wives do not live in economic longanimity, nor are their characters given any other emotional dimensions apart from shouting at each other. Indeed, Jamil rarely spends time with his wives, lies to them and has never been shown as a family man. Although this film is about building a family, or rather families, there is no family photos to be seen in the first two marriages. His relationship with his two wives is seen as just a tool that propels the hero journey narrative to his eventual third marriage to Rohani - reaffirming his masculinity.

The obvious absence of the family photo in the first two acts of the film is remedied when a family photo was shown during the climactic scene. In this scene at Rohani's house, the photo of Rohani and Jamil is used to expose the third marriage that leads to the plot resolution. In that vein, the film uses a family photo as a piece of the puzzle that needs to be assembled to eventually lead to the happiness of the male protagonist, Jamil. In addition to that, as that is the only family photograph shown in the film, it is also the family that Jamil feels most welcome. At the ideological level, putting a family picture together equates the idea of putting the family together, the chasing scenes that ensue the revelation is necessary to not only provide comic relief but also to bring the three wives (read as Jamil's ultimate control of his marriages) together. As that is the only family portrait that exists in a drama about building a family, P. Ramlee compensates that lack by providing a family snapshot at the very end of the film. This is evident in the closing scene, that is, after getting caught in a shallow river and making a promise to treat the wives equally, the three wives walk together with Jamil to denote the idea of acceptance of each other. Then Jamil addresses his "luck" by showing the Victory sign to the audience, or the camera - not only breaking the fourth wall but also declaring that he is the master of the game. The ending of the film, with a collage of photos that are curated as a family photo album, is an apt conclusion to a politic of heteromasculinity whose homogenizing power is sealed by the film's fairy tales happy ending. 
Meanwhile, the theme of courting in romantic love is explored by P. Ramlee using dramatic irony in Masam Masam Manis (1965). Dramatic irony grants the audience a privileged position of knowing what both characters do not know, and with this dramatic technique, comic moments are created by P. Ramlee. On the surface level, the film is a story of Cikgu Shaari and Nurkiah who are neighbours and hate each other's guts. Shaari works a schoolteacher during the day and a nightclub singer at night. Nurkiah works as a nightclub singer, but introduce herself as a kindergarten teacher. Both the school and the nightclubs are markers of modern milieu these characters are in. This is a comedy of character, and it centers around the protagonists' hostile behaviours as neighbours who did not know each other, but finally fell in love. In this film, Nurkiah is established as Cikgu Shaari's foil, providing both a romantic and antagonistic force that propels the narrative into the comedy genre territory. Unbeknownst to them as they never meet each other inside the lodge they are renting, they have fallen in love with each other. In one scene when Nurkiah fails to meet him for a date as promised, he returns home feeling frustrated and stares at her photo. Likewise, for Nurkiah who misses him. In the context of romantic love, the whole shenanigan that culminates in their eventual realization that they have been the feuding neighbours can be interpreted as merely a fantasy of heterosexual foreplays and comedy is used to cushion the sexual tension.

Therefore, it can be seen that in this film, photographs are used as climacterics of their relationship; each stage of their love story is marked by the use of photographs. For that reason, photographs appear in several defining scenes. One of them is when his alarm clock went off. There is a photo of a faceless woman next to his bed, indicating that he is single. The question mark on the photo opens up the question of his ideal woman. True to this role of capturing every romantic development of the protagonists, the film ends with a family photo captured by Shaari himself. Explaining that after 5 years of marriage, they are blessed with 10 children, 2 twins per year, the family photo cements the ability to gain romantic love, its permanence. The family photo reinforces Shaari's prowess as a heterosexual man, hence reaffirming his masculinity and the need to retain family values and conventions - he as a successful modern husband with an established career in education and Nurkiah a housewife. This again, similar to Madu Tiga, the fairy tales ending only showcases Shaari's masculine prowess, and the organization of this power structure is mechanically captured by Shaari when taking his family portrait.

If Madu Tiga and Masam Masam Manis apotheosize romantic love via comedy, Sesudah Subuh (1967), on the other hand, foments romantic disillusionment with its realist drama that epitomizes a quiet masculine cri de coeur. Sesudah Subuh wears its emotion on its slowly paced narrative, reinforced by the numbness of a routinized existence of the male protagonist, Arifin. The film starts with a wide angle shot of the city, before zooming in into the front of a flashy house and then a man getting dress for work. This visual technique is mechanical and it serves a bifurcate function. One, it informs the audience that this is an urban life story with its urban problem. Two, it is effective in creating contrast by positioning Arifin as a modernist subject whose existence is dwarfed by his own modern surrounding that is akin to the protagonist in Joseph Conrad's novels. As a result of this contrast, the audience is made to painfully watch his mechanized movement from a short distance. The distance that is not intimate enough so as to be immersed into his emotion, but it is close enough to turn the viewers into unwilling observers and sharers of the boredom and burden of his life. It is hard to be sympathetic towards him at this stage as he is not be given enough backstory to 
relate to. Despite such a routine life, him forgetting to bring his suitcase to work is a testimony of an emotionally numb existence.

From the beginning, the film's mood is neither atmospheric nor emotional; this ambivalence becomes the film's central conceit. The sense of detachment and lovelornness comes from an arid existential place that cinema is able to create with camera spaces that the protagonist walks into without much effort or consideration. Perhaps this lack of effort and consideration stems from the idea that everything in his life seems to be rehearsed yet desultory, and that rehearsal feeling is demonstrated by camera movements that seem to always be contrived ready for him to walk into. He is so emotionally hopeless that even his steps are prepared by the camera. This is demonstrated at the outset of the film when Arifin is shown as a well-dressed and gentlemanly mannered man in his own bedroom while his wife, Salmi, is still asleep. He is polite in answering the phone, seeming to be unaffected by what his wife is up to. When his gardener expresses his pity, Ariffin succinctly responds: "Why should you? It is my fate". This sense of resignation, the refusal to inveigh against his familial estrangement, underlines the reason for his emotional numbness, that is, a form of existential mea culpa. What this mood does is that it juxtaposes Ariffin's sense of surrender with that of his family's contumacious attitude towards him, as well as a sense of longueur. These are captured by him gingerly entering the camera frame.

This sense of resignation is cinematically exteriorized in two cognizable figures - the Other and his family photos. In one scene, Ariffin finds an avenue to express his "dreary and frustrated existence" to one of his clients, Allen, a Chinese man who came to deliver his payment, confiding in him that he feels like a stranger in his own house. Allen is the Other because he is a stranger of whom Ariffin finds growing resonance as Allen's otherness peters out as he becomes a deuteragonist in the course of the story. It is via Allen that the depth of Ariffin's character is gradually revealed. Another one is his family photos. After returning home the night he meets Allen, he looks at the individual photos of his wife and children, Salim and Salmiah, on the wall. There is no photo of him, reinforcing the sense of alienation that he experiences in the domestic sphere. Therefore, the Other and the family photos are used to reinforce the sense of resignation that Ariffin is experiencing.

Although throughout the film Ariffin is normally placed in the middle of a shot, his presence is not imposing and therefore cannot connote the idea of power. Susan Sontag, in her groundbreaking essay On Photography famously observes that,

"[t]o photograph is to appropriate the thing photographed. It means putting oneself into a certain relation to the world that feels like knowledge - and, therefore, like power" (1977, p.174).

The photos, curated in such a way, with the photo of his wife flanked by his children's, is designed to exclude him. In this shot, the photo of his wife is in the middle of the frame while he stands at the corner of it, with his back facing the camera. There is no reverse reaction shot provided, as if not allowing the audience to see how he feels or reacts. The photos, in the context of this film, do not represent the "has been" - its semiotic function that photos are usually designed to do. The photos on the wall represent the etiolated state of Ariffin's family affair, and maybe as a subterfuge of his future too. For that reason, Sesudah Subuh ventures into a psychological drama genre territory and the family portrait reveals not about his power, but his psychological state of affair. 
The theme of gender politics between Ariffin and his wife is then transposed into the family photo, further demonstrating how Ariffin truckles to romantic disillusionment. He accepts that the family is no longer there for him and his bookstore is admittedly an escape. In the scene that follows after Ariffin looks at the family photos, the camera cuts to his busy wife and children doing their own things, collimating temporal space of their personal narratives to aggrandize his sense of alienation. Then the camera cuts to a clock above the photo of his wife to indicate that his family has stayed on until the wee hour in the morning. From the clock and the photos, the camera tilts downward showing Ariffin sleeping on his single bed (This single bed is a result of censorship that prohibits the use of double bed even in a marriage context). The effect of this tilt is that it immediately links the notion of the power of his wife over him, who seems to be moribund, helpless and out of control in his sleep. The photo, being in that position and in itself is permanent and standoffish, also creates a sense of surveillance, an omnipresence, reflecting that Salmi has control over Ariffin.

Akin to the theme of romantic disillusionment due to gender politics is Ariffin's struggle for masculine validation. This masculine validation is explored by P. Ramlee with the deconstruction of the insider/outsider divide. In this film, it is the outsiders (Chandra, Alice \& Allen) who seems to have compassion for Ariffin and who are willing to transgress his private space - reified emotion as epitomized by his hostile house. In one instance, through the confrontation between Chandra and Salim that Ariffin's emasculation is given a reason his ostensible lack of wherewithal. This lack is compensated by the figures of two non-Malay ladies, Chandra and Alice, who come as a saviour to Ariffin. Therefore, this recalls the intertwine of racial and gender politics in which minority women tend to be associated with the castrated figure, and in this film, Ariffin encapsulates that castration. This explains why these women are more sympathetic to Ariffin. In a scene in which Salim's Indian girlfriend, Chandra, blames Salim for being rude to Ariffin, Salim vitriolically remarks: "He is irresponsible! Luckily, he still has my mum. If not, he would have been a beggar!" (Subtitle). Later, when Chandra confronts Ariffin, he haplessly admits to what his son has said about him, reducing Chandra to tears. Before she storms out, she turns and looks at Ariffin, declaring "Uncle, as long as I live, I will not let anyone hurt you. Not even your own son". Unfortunately, this further signifies his masculine lack. Likewise, the presence of Alice in Ariffin's life, with her helping at the shop and accompanying him on his much-needed holiday, reduces his masculinity to a zero, and him embarking in an affair is a proof of his castration.

The resolution of the conflict between Ariffin and his family functions as a metaphor for returning to tradition. So hopeless was Ariffin that even the revelation that results in his family appealing for him to come back is done by Allen, in characterization term, his deuteragonist. Allen explains that his wife, Alice, is asked to befriend him to teach Ariffin's wife a lesson. This inevitably evinces the idea that the modern state of Malaya then was both racialized and gendered, with Ariffin's Malay masculinity is negated by Allen's masculinity and, to a certain extent, his own dead father who asked Allen to give him the money. With his dead's father involvement - which epitomizes the past intruding into the present modern Malay masculinity is shown as shackled by tradition. For that reason, while there is a fairy tales ending feel to this film, it evokes the sense of reluctance and is inorganically developed. This is because, after Ariffin is made aware of his standing, he quickly runs up the airport stairs while ignoring his family to watch Allen and his wife boarding the Malaysian Airline. This is the most kinetic and emotional moment in the film as it symbolizes a moving on, with Allen (a Chinese family man) embarking on a new journey in a modern invention (the airplane), while he is stuck with his family - a traditional structure that has been oppressing 
him. The framing of family photos from the beginning (the opening credit of the film is curated as a family photo album when each character is introduced as a family - Malay, Chinese and Indian family) until the ending with a performance of a "portrait" of a happy family is a hallmark of family as a site of conflict for modern Malay masculinity.

\section{CONCLUSION}

Family portraits in Malay films in the 1960s, particularly P. Ramlee's Madu Tiga, Masammasam Manis and Sesudah Subuh, capture the essence of their time, that is, the transition from the immediate post-independence of Malaya in 1957 and the formation of Malaysia in 1963. The crisis of the family, as documented by the family photo, becomes the source of conflict of the modern Malay masculinity. The way family portraits are curated in these films reveals the way the family is romanticized, amid the challenges faced by the modern world. As the family portrait denotes the idea of permanence, it therefore, provides a stark contrast to the ever-changing raison d'etre of a nation in transition, revealing themes of romantic disillusionment and masculinity and its discontent.

The three films analyzed, although of two different genres, comedy and drama, exemplified how family portraits are used to conjure up the problematics in the idea of a return to the old value, or tradition. While the comedy films provide criticism of Malay masculinity by revealing its flaws, the films are framed within the hero journey narrative that eventually becomes the harbinger of the "coming of age" fairy tales happy ending as epitomized by the portrait of the family at the end of both films. In short, the man-child eventually becomes an adult man and the family portrait is the testimony of that. Meanwhile, Sesudah Subuh as a psychological drama, ironically sans its psychology, uses the family as a source of Malay masculine anxiety associated with the traditional values and the family portrait provides the visual evidence of this shackle. In conclusion, although the family portraits in the three films are meant to be innocuous to Malay masculinity in crisis, it is ideologically a folie de grandeur about the family and what it stands for the nation in transition.

\section{BIODATA}

Jamaluddin Bin Aziz PhD is an associate professor in Critical Media Studies at the Center for Media and Communication Research, Faculty of Social Sciences and Humanities, UKM. His areas of research interest include media and communication, culture, gender, screen studies, discourse analysis and digital humanities. Email: jaywalk@ukm.edu.my 


\section{REFERENCES}

Anderson, B. (1991). Imagined communities. London: Verso.

Althusser, L. (2004). Ideology and ideological state apparatuses. In Rivkin, J. \& Ryan, M. (Eds.), Literary theory: An anthology (pp. 693-702). Blackwell Publishing: Oxford.

Barnard, T. P. (2005). Sedih sampai buta: Blindness, modernity and tradition in Malay films of the 1950s and 1960s. Bijdragen tot de Taal-, Land-en Volkenkunde (BKI) Journal of the Humanities and Social Sciences in Southeast Asia, 161(4), 433-453.

Barnard, T. P. (2010). Film Melayu: Nationalism, modernity and film in a pre-World War Two Malay magazine. Journal of Southeast Asian Studies, 41, 47-70.

Barthes, R. (1981). Camera Ludica: Reflections of photography (Trans. by Richard Howard). Vintage Classics: Farrar, Straus and Giroux Publishing.

Becker, H. S. (1974). Photography and sociology. Studies in Visual Communication, 1(1), 3-26.

Cartwright, L., \& Wolfson, E. (2015). Introduction: Affects at the limit of photography. Journal of Visual Culture, 17(2), 141-151.

Hariman, R. (2018). Love in the ruins? Or, photography's radical promise. Explorations in Media Ecology, 17(4), 491-497. https://doi.org/10.1386/eme.17.4.491_1

Hasan Sazali, \& Lutfi Basit. (2020). Meta analysis of women politician portrait in mass media frames. Jurnal Komunikasi: Malaysian Journal of Communications, 36(2), 320-334.

Humm, M. (2003). Modernist women and visual culture. New Jersey: Rutgers University Press.

Li, Z., \& Zeng, Y. (2019). The connotation interpretation of typology photography. 2019 9th International Conference on Education and Social Science (ICESS 2019), Francis Academic Press, United Kingdom (pp. 1773-1776). Retrieved from https://webofproceedings.org/proceedings_series/article/artld/7526.html

McGlynn, A. (2010). Fathers, daughters and masculinity in crisis in contemporary fiction (PhD. Thesis, Graduate Department of English, University of Toronto).

P. Ramlee. (1964). Madu tiga [film]. Malay Film Productions Ltd.

P. Ramlee. (1965). Masam-masam manis [film]. Merdeka Filem Studio.

P. Ramlee. (1967). Sesudah subuh [film]. Merdeka Filem Studio.

Parsons, S. (2009). Sontag's lament: Emotion, ethics, and photography. Photography and Culture, 2(3), 289-302. http://dx.doi.org/10.2752/175145109X12532077132356

Rousseau, J-J. (1762, 2012). The body politic (Trans. by Quintin Hoare). Milton Keynes: Penguin Random House.

Schirato, T., \& Webb, J. (2004). Understanding the visual. London: Sage Publication.

Scott, A. O. (2011). On (digital) photography: Sontag, 34 years later. The New York Times. Retrieved on 2020, August 15, from http://www.nytimes.com/2011/05/08/magazine/mag-08Riff-

t.html?pagewanted=print

Sontag, S. (1977). On photography. Retrieved from http://writing.upenn.edu/library/SontagSusan-Photography.pdf

Sontag, S. (2003). Regarding the pain of others. New York: Picador. Retrieved from https://monoskop.org/images/a/a6/Sontag_Susan_2003_Regarding_the_Pain_of_O thers.pdf

Sturken, M., \& Cartwright, L. (2009). Practices of looking: An introduction to visual culture. Oxford: Oxford University Press.

Zawawi Ibrahim. (2007). The beginning of neo-realist imaginings in Malaysian cinema: A critical appraisal of Malay modernity and representation of Malayness in Rahim Razali's films. Asian Journal of Social Sciences, 35, 511-527. 